\title{
METODE ISTINBĀT HUKUM JARINGAN ISLAM LIBERAL (JIL)
}

\author{
Arif Susandi*
}

\begin{abstract}
The methods of interpreting al-Qur'an often elaborate upon philosophy, lest, and reality and those give new perspectives towards some controversies in Islamic laws. This chapter explains about one method which is practiced by Islamic Liberal Network (IIL). Commonly JIL contributes the rational thought and it is based on the maslabah principles.
\end{abstract}

Kata kunci: metode istinbăt, maṣlahah, pemikiran rasional.

\section{A. Pendahuluan}

Jaringan Islam Liberal (JIL) secara resmi didirikan pada tanggal 8 Maret 2001 di Jakarta. Pada mulanya ia adalah sebuah forum diskusi melalui milis (islamliberal@yahoo.com) yang telah ada sejak tahun 1999 (setalah lengsernya Soeharto). Enam aktivis mudanya yang telah bertemu Gunawan Muhammad pada tanggal 4 Januari 2001 mulai merekrut para mahasiswa dan intelektual untuk bergabung di milis tersebut. Mereka memutuskan untuk menggunakan jaringan, bukannya organisasi, asosiasi, ataupun partai politik. Sebagai contoh Hamid Basyaib berargumen bahwa JIL adalah

* Mahasiswa STAIN Purwokerto Jurusan Syariah Program Studi Ahwalus Syakhsiyyah angkatan 2003. 


\section{Syufaat}

gerakan intelektual dan kultural, oleh karena itu ia bukanlah partai politik, organisasi, atau sekte agama yang mempunyai ritual yang ketat dengan sanksi dan hukuman. Oleh karena fokusnya adalah melawan fundamentalisme, JIL memilih untuk mewadahi diri mereka dalam bentuk jaringan, bukannya sebagai organisasi yang ketat atau melibatkan diri dalam partai politik. Dengan demikian JIL merupakan aliansi yang terbuka bagi siapapun yang mempunyai keinginan untuk mempublikasikan ide-ide Islam liberal. Tulisan ini akan menjelaskan sedikit mengenai metode istinbät hukum yang merupakan poros perdebatan para ahli hukum Islam.

\section{B. Sumber-sumber Hukum Islam}

1. Al-Qur'an.

Al-Qur'an dalam kajian usul fikih merupakan obyek utama dan pertama kajian dalam memecahkan suatu hukum. Al-Qur'an menurut bahasa berarti "bacaan" dan menurut istilah usul fikih ia berarti kalam (perkataan) Allah yang diturunkan-Nya dengan perantaraan Malaikat Jibril kepada Nabi Muhammad dengan bahasa Arab dan membacanya adalah ibadah. ${ }^{1}$ Pandangan Jaringan Islam Liberal tentang al-Qur'an terepresentasikan dalam dua tema besar sebagai berikut:

a. Al-Qur'an sebagai teks terbuka

Memahami al-Qur'an dengan membiarkan ia berbicara sendiri, menurut Yusuf Rahman, ${ }^{2}$ disebut dengan penafsiran yang berpusat pada teks (text centered interpretation). Metode ini dilakukan dengan menganalisa arti bahasanya, gaya bahasanya, maupun struktur bahasa. ${ }^{3}$ Tafsir al-Qur'an hanya bersandar pada teks dan teks dianggap sebagai benda yang diam. Zuhairi Misrawi yakin bahwa al-Qur'an adalah teks yang terbuka. Maksudnya al-Qur'an bukanlah barang antik

${ }^{1}$ Satria Effendi, Usbul Fiqib (Jakarta: Prenada Media, 2005), hal. 79.

${ }^{2}$ Yusuf Rahman, "Pluralitas Penafsiran al-Quran", dalam Ijtibad Islam Liberal, hal. 12.

${ }^{3}$ Penafsiran seperti ini dapat dilihat pada tafsir Jalalain. 
yang tidak dapat dijamah sama sekali. Dalam bahasa yang lebih sederhana, dibutuhkan kerja-kerja penafsiran yang mempunyai relevansi dengan konteks masyarakat pembaca. ${ }^{4}$ Pembacaan tidak lagi hanya terpusat pada teks akan tetapi harus menghargai peran pembaca atau penafsir, reader centred interpretation, meminjam istilah Yusuf Rahman, ${ }^{5}$ yakni menekankan pentingnya peran pembaca di dalam mencari dan memberikan makna suatu teks. Para pemerhati kajian al-Qur'an sebenarnya menyadari potensi problem dalam menafsirkan Kitab Suci. Hal ini terlihat dengan upaya mereka untuk mengembangkan apa yang kita kenal sebagai 'ulum alQur'an, di dalamnya dibangun pagar-pagar agar produk tafsir itu "benar". ${ }^{6}$ Sebagai teks, al-Qur'an mempunyai karakter yang terbuka, bahkan progresif, yaitu membangkitkan lahirnya berbagai macam pendapat, bahkan ia telah mendorong umat untuk menghasilkan perubahan progresif. ${ }^{7}$

b. Al-Qur'an sebagai produk budaya

Al-Qur'an selain sebagai “teks wahyu” juga sebagai "teks budaya" yaitu teks yang sangat erat hubungannya dengan budaya. Dalam posisinya sebagai teks wahyu umat Islam meyakini bahwa al-Qur'an adalah wahyu yang diturunkan oleh Allah melalui malaikat Jibril kepada Nabi Muhammad SAW. Kemudian al-Qur'an dalam Posisinya sebagai teks yang

${ }^{4}$ Zuhairi Misrawi, Al-Qur'an Kitab Toleransi, (Jakarta: Fitrah, 2007), hal. 64.

${ }^{5}$ Rahman, "Pluralitas...", hal. 13.

${ }^{6}$ Kusmana, "Tafsir al-Qur'an Inklusiv", WWW.islamblib.com, didownload pada tanggal 12 November 2008. Di antara pagar-pagar yang dikembangkan adalah asbäb al-nuzunl, pendasaran terhadap penjelasan al-Qur'an yang disampaikan generasi pertama (Nabi dan Sahabat), $t a b i^{*}$ dan $t a b i^{i}$ al-tabi in. Pendasaran ini menurut Kusmana adalah prinsip dasar dari metode tafsir yang dikenal dengan al-tafsir bi al-mathür, kaidah kebahasaan, abrogasi (prinsip penyelesaian kontradiksi antar ayat dalam aspek hukum atau redaksinya), sampai pada persyaratan integritas moral dan otoritas keilmuan penafsir. Dalam pengembangan pagarpagar penafsiran tersebut telah terjadi ortodoksi tafsir al-Qur'an bahkan sampai pada kesimpulan bahwa tafsir yang benar adalah tafsir yang sejauh mungkin bisa memagari keterlibatan subyek, akal, ideologi dan madzhab penafsir. Artinya, tafsir yang selama ini dianggap "benar" adalah penafsiran yang berpusat pada teks (text centered interpretation).

${ }^{7}$ Misrawi, al-Qur'an..., hal. 70. 


\section{Arif Susandi}

erat hubungannya dengan budaya belum mendapat perhatian yang semestinya khususnya perihal dimensi linguistik dan historisitas kodifikasi al-Qur'an. ${ }^{8}$ Faktanya al-Qur'an pada masa awal turunnya adalah berbentuk verbal dan baru dikodifikasikan pada zaman Usman ibn 'Affan. Kodifikasi al-Qur'an yang dilakukan oleh Usman memang tidak berjalan dengan mulus dan banyak terjadi kontroversi di antara para sahabat meskipun pada akhirnya Usman berhasil menyelesaikannya dan kemudian memusnahkan seluruh mushaf lainnya yang tidak disepakati.

Apa yang dikemukakan oleh Jaringan Islam Liberal kongruen dengan tesis dari Nasr Hamid Abu Zaid yang menyatakan bahwa budaya Islam adalah budaya tekstual, kebudayaan yang selalu berlandaskan kepada teks, yakni al-Qur'an dan alHadis. Al-Qur'an, meskipun ia adalah wahyu dari Allah SWT akan tetapi tidak dapat dilepaskan dari konteks historis pada waktu al-Qur'an diturunkan. Al-Qur'an adalah jawaban atas tantangan umat Muhammad SAW waktu itu, sehingga alQur'an merupakan produk budaya, menyejarah, dan dapat dikritik, layaknya teks-teks lain. ${ }^{10}$

Menurut Ulil, sejak menit pertama proses gradual penurunannya, al-Qur'an telah menjadi pokok persoalan di

${ }^{8}$ Ibid., hal. 66 .

${ }^{9}$ Mengenai pandangan kritis JIL terhadap kodifikasi al-Quran dapat dilihat pada Luthfi Assyaukanie, "Merenungkan Sejarah al-Qur'an", dalam Ijtihad Islam Liberal, hal. 1. Assyaukani mempertanyakan dan meragukan apakah al-Qur'an mulai dari surat al-Fâtihah sampai al-Nâs adalah kalam Allah yang diturunkan kepada Nabi Muhammad baik kata maupun maknanya? Menurutnya al-Qur'an adalah kalam Allah yang diwahyukan kepada Nabi Muhammad tetapi kemudian mengalami berbagai proses "copy editing" oleh para sahabat, tabi in, ahli bacaan, qurrâ, otografi, mesin cetak, dan kekuasaan.

${ }^{10}$ Lihat Nasr Hamid Abu Zaid, Tekstualitas al-Qur'an, terj. Khoiron Nahdliyyin, (Yogyakarta: LKIS, 2005), hal.29-61. Pemahaman Jaringan Islam Liberal mengenai alQur'an memang sangat dipengaruhi oleh pemikiran Abu Zaid. Al-Qur'an adalah produk budaya sehingga bersifat historis dan lokal (Arab). Al-Qur'an sama halnya dengan teks-teks lain yang tidak bisa lepas dari kritik. Al-Qur'an sebagai sebuah teks, pada dasarnya merupakan produk budaya. Artinya teks terbentuk dalam realitas dan budaya melalui rentang waktu lebih dari duapuluh tahun. 
kalangan orang Arab yang menyaksikan turunnya wahyu. AlQur'an dengan cukup baik merekam fenomena ini dalam Q.S. al-Furqān: 32:

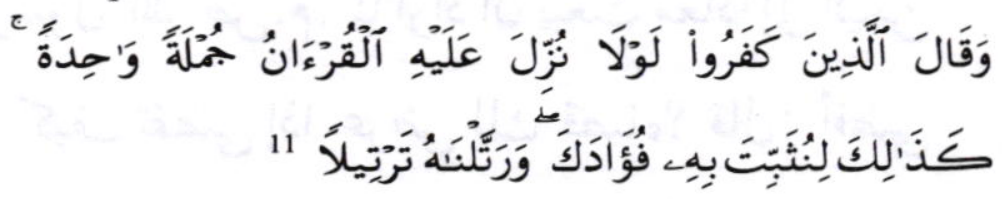

Menurut Adian Husaini pemahaman seperti ini berbahaya karena penafsiran terhadap al-Qur'an dianggap banyak mengandung problem lantaran rentang waktu dan situasi yang sangat jauh berbeda antara dulu dan sekarang. Dengan demikian perlu adanya upaya tafsir ulang, termasuk tafsir terhadap ayat-ayat mubkamät sekalipun di mana hal ini dianggap sebagai dinamisasi ayat-ayat al-Quran dan merupakan prestasi akal yang brilian. ${ }^{12}$ Keyakinan Jaringan Islam Liberal akan historisitas teks al-Qur'an semakin menemukan penguatan ketika ditemukan adanya metode pemahaman al-Qur'an klasik yang mempertimbangkn asbäb al-nuzül dan näsikb mansükeh. ${ }^{13}$

\section{Al-Hadis}

Mengenai kehujjahan hadis sebagai sumber hukum Islam dapat

\footnotetext{
"Pernyataan tersebut timbul di'kalangan orang-orang Arab karena adanya asumsi yang tidak seluruhnya tepat bahwa wahyu-wahyu yang turun pada Nabi-Nabi sebelum Muhammad bersifat jumlah wabidah. Tatkala orang-orang Arab mempertanyakan mengapa tidak diturunkan sekaligus? Jawaban yang diberikan Allah sangatlah menarik yakni, kajälika li nuíabbita bibi fu'ädak, warattalnäbu tartỉlä.Ulil menerjemahkan ayat tersebut dengan "pencicilan itu Aku (Allah) lakukan agar Aku membuat hatimu senang dan kukuh, (dan sekalipun ayat-ayat itu turun secara bertahap, tetapi) Aku susun kembali begitu rupa sehingga menjadi berurutan dan tertib (tartil)." Lihat Abdalla, Menyegarkan Kembali, hal. 180.

${ }^{12}$ Adian Husaini, "Kritik Hermeneutik al-Qur'an," dalam WWW.islamlib.com, didownload pada tanggal 12 November 2008.

${ }^{13}$ Historisitas teks al-Qur'an menurut Jaringan Islam Liberal lebih masuk akal karena untuk mendukung budaya masyarakat Arab yang masih bersifat oral, bukannya budaya tulis. Pencicilan al-Qur'an mendukung dan memudahkan para Sahabat Nabi untuk mengahafal. Dengan memahami konsep historisitas teks al-Qur'an Jaringan Islam Liberal, bisa ditarik kesimpulan bahwa teks al-Qur'an adalah respon terhadap fenomena sosial yang terjadi pada masyarakat Arab. Oleh karena itu, wahyu sangat terpengaruh oleh determinasi sosial historis, artinya wahyu ditentukan, dikondisikan, dan dipengaruhi oleh keadaan sekitar.
} 


\section{Arif Susandi}

dilihat pada rekaman peristiwa diutusnya Mu'az ibn Jabal ke Negeri Yaman oleh Rasul sebagai berikut: ${ }^{14}$

$$
\begin{aligned}
& \text { ان رسول الله ص.م. للا أراد أن يبعث معاذا إلى اليمن } \\
& \text { قال: كيف تقضى إذا عرض لك قضاء؟ قال: أقضى } \\
& \text { بكتاب الله قال: فإن لم بحدل في كتاب الله قال: فبسنة } \\
& \text { رسول الله ص. م. قال : فإن لمجحد ونى سنة رسول الله } \\
& \text { ص. م. ولا خن كتاب اللّ. قال: أجتهد رأيى ولا آلو • } \\
& \text { فضرب رسول الله ص.م. صدره وقال: الحمد للّ الذىى } \\
& \text { وفق رسول رسول الله لا يرضى رسول الله }
\end{aligned}
$$

Posisi hadis sebagai sumber hukum Islam yang kedua diakui oleh Jaringan Islam Liberal. Hadis kedudukannya adalah sebagai penjelas terhadap al-Qur'an. Pandangan Jaringan Islam Liberal mengenai kedudukan hadis tidak jauh beda dengan mayoritas ulama. Akan tetapi kendati mengakui hadis sebagai sumber hukum Islam namun ia tetap harus diteliti kembali secara kritis. Dari segi sanad, hadis telah diseleksi secara ketat pada masa tadwin untuk mencari hadis yang benar-benar sahih. Tatapi Ulil Abshar Abdalla berpendapat bahwa untuk menyatakan hadis bernilai sahih ataupun sebaliknya, tidak cukup hanya dilihat dari segi sanadnya saja akan tetapi harus juga kritisi dari segi matannya. Kritik matan hadis menurut Ulil adalah bidang yang sangat tertinggal perkembangannya dalam ilmu hadis. Banyak hadis yang tidak sesuai dengan semangat al-Qur'an, misalnya hadis tentang perintah membunuh orang murtad. Bagi Ulil, ini

${ }^{14}$ Lihat Abū Dāwud Sulaiman ibn al- Ash'ath al-Sijistāni, Sunan Abī Dānud (Beirut: Dār al-Hadith, 1999), I: 494. 
bertentangan dengan semangat là ikrāha fi al-dìn. Ulil tidak menerima hadis tersebut dari segi matan atau sekurang-kurangnya, harus ditafsir ulang. ${ }^{15}$

\section{Pendekatan Hermeneutik dalam Memahami Nas Syarak}

Istilah hermeneutik atau hermeneutika merujuk pada nama dewa Yunani kuno yang bernama Hermes yang tugasnya menyampaikan berita dari Sang Maha Dewa (Zeus) kepada manusia. ${ }^{16}$ Sebenarnya banyak teori hermeneutika yang telah berkembang, akan tetapi di sini penulis hanya akan memaparkan teori hermeneutika Nasr Hamid Abu Zaid. Hal ini penulis lakukan karena teori hermeneutika Abu Zaid sejak permulaan dipersiapkan untuk membedah al-Qur'an dan hadis.

Pemahaman Abu Zaid tentang makna dan signifikansi secara umum diderivasi dari Hirsch. "Makna" adalah makna yang dipresentasikan oleh teks dan signifikansi adalah apa yang muncul dalam hubungan antar makna dan pembaca. Dengan demikian makna adalah "makna kontekstual original, yang hampir-hampir mapan (fixed) disebabkan historisitasnya" sedangkan signifikansi "bisa berubah" (bangable). ${ }^{17}$ Abu Zaid membedakan antara makna yang dimaksud penulis dan makna yang dipergunakan oleh teks. Dia lebih menekankan pada makna yang terakhir, apabila makna bergantung

${ }^{15}$ Ulil Abshar Abdalla, "Soal Kedudukan Hadis", dalam islamtibera@yaboogroup.com, didownload pada tanggal 12 November 2008. Penjelasan tentang kriteria sahih, hasan, dan da if dapat dilihat dalam Muhammad Hashim Kamali, Prinsip dan Teori-teori Hukum Islam, (Yogyakarta: Pustaka Pelajar, 1996), hal. 101.

${ }^{16}$ Menurut Husseien Nasr sebagaimana dikutip oleh Komaruddin Hidayat, Hermes tidak lain adalah Nabi Idris. Hermeneutika, yang diambil dari peran Hermes, adalah sebuah ilmu dan seni menginterpretasikan sebuah teks. Bagi Hermes persoalan yang pertama dihadapi adalah bagaimana menafsirkan pesan Tuhan yang berbicara dengan bahasa "langit" agar dapat dipahami oleh manusia yang berbicara dengan bahasa "bumi". Sejak awal hermeneutika berurusan dengan tugas menerangkan kata-kata dan teks yang dirasakan asing oleh masyarakat (alien speech), baik ia datang dari Tuhan maupun yang berbicara dengan bahasa langit maupun yang datang dari generasi terdahulu yang hidup dalam tradisi dan juga bahasa yang "asing". Komaruddin Hidayat, Memahami Bahasa al-Qur'an, Sebuab Kajian Hermeneutik, Jakarta: Paramadina, 1996), hal. 125-126.

${ }^{17}$ Mochamad Nur Ichwan, Meretas Kesarjanaan Kritis al-Qur'an (Jakarta: Teraju, 2003), hal. 89 . 


\section{Arif Susandi}

pada meksud penulis, yaitu Allah SWT, hal ini akan menutup makna dari signifikansi apapun.

Kata-kata literal (mantūq) teks al-Qur'an bersifat ilahiyah, namun ia menjadi sebuah "konsep" (majh $\overline{u m}$ ) yang relatif dan bisa berubah ketika ia dilihat dari perspektif manusiawi. Menurut Abu Zaid realitas adalah dasar. Dari realitas dibentuklah teks (al-Qur'an) dan dari bahasa dan budayanya terbentuklah konsepsi-konsepsi (mafäbim). Di tengah-tengah gerak interaksi dengan manusia terbentuklah makna (dalälab). ${ }^{18}$ Wilayah teori Abu Zaid tentang alQur'an adalah wilayah pemahaman terhadap al-Qur'an secara sosiologis bukan teologis. Yang terpenting dari konsep yang ditawarkan oleh Abu Zaid adalah dalam memahami teks al-Qur'an seseorang harus paham akan tiga level makna pesan dalam level teks, secara ringkas konsep level teks dapat dijelaskan sebagai berikut:

1. Teks level pertama, yaitu makna yang hanya menunjuk kepada bukti atau fakta historis yang tidak dapat diinterpretasikan secara metaforis. Misalnya ayat tentang tentara gajah.

2. Teks pada level kedua, yaitu makna yang menunjuk kepada bukti atau fakta historis dan dapat diidentifikasikan secara metaforis, misalnya ayat tentang penggambaran surga.

3. Teks pada level ketiga, yaitu makna yang dapat diperluas berdasarkan atas signifikansi yang diungkap dari konteks sosio kultural dalam teks itu berada. Misalnya ayat tentang waris maupun poligami.

Hubungan antara pikiran, bahasa, dan wacana adalah merupakan salah satu agenda pokok kajian hermeneutik. Yaitu mengkaji pikiran dan perasaan orang yang telah terlembagakan dalam bahasa tulis, sementara pembicaranya sudah tidak ada. ${ }^{19}$ Artinya

\footnotetext{
${ }^{18}$ Moch. Nur Ichwan, “Al-Qur'an sebagai teks, teori teks dalam hermeneutik alQur'an Nasr Hamid Abu Zaid', dalam Studi al-Qur'an Kontemporer, ed. Abdul Mustaqim dan Syahiron Syamsudin, (Yogyakarta: Tiara Wacana, 2002), hal. 158-159.

${ }^{19}$ Komaruddin Hidayat, Memahami Bahasa al-Qur'an, Sebuab Kajian Hermeneutik, Jakarta: Paramadina, 1996), hal. 130.
} 
ketika pembaca menghadapi teks ia harus sadar bahwa sebenarnya ia menghadapi "dunia lain", yaitu dunia teks dan dunia konteks. Teks tidak bisa dilepaskan dari konteks yang melingkupinya ketika sang author melembagakan pemikirannya. Ia lahir dari pemikiran yang saling berbenturan dengan konteks sosial masyarakat. Hal yang ingin dijembatani oleh hermeneutika adalah kesenjangan antara pembaca dan penulis, yang mana keduanya dihubungkan oleh teks. Persoalan lain yang hendak diselesaikan oleh hermeneutika adalah persoalan mengenai adanya jarak dan perbedaan bahasa, tradisi, dan cara berpikir antara teks dan pembaca karena bahasa dan muatannya tidak bisa dilepaskan dari kultur. ${ }^{20}$

Terlepas dari hal di atas, menurut Jaringan Islam Liberal penyelesaian terhadap paradoks yang bersifat isu dan gagasan belum banyak dilakukan. Gagasan tentang pluralisme agama dalam alQur'an, misalnya. Di dalam satu spektrum, pluralisme ala Qur'an diungkapkan melalui janji penyelamatan terhadap orang-orang yang beragama selain Islam (QS. al-Baqarah: 62). Sementara pada spektrum yang lain, absolutisme Islam juga terpampang dengan tegas dalam al-Qur'an. Hal ini harus diatasi untuk memungkinkan tegaknya sebuah tata kehidupan berdampingan secara damai dengan umat agama lain. ${ }^{21}$ Dengan metode tafsir hermeneutika Jaringan Islam Liberal hendak membuat produk tafsir yang lebih rasional dan hendak lepas dari pagar-pagar metode tafsir klasik yang kurang mementingkan kondisi sosio historis. Singkat kata, metode yang

${ }^{20} \mathrm{Ibid}$, hal. 134. Di dalam berhadapan dengan suatu teks, proses penjarakan tidak hanya terjadi antara si pengarang dan pembaca (distanciated from the author), akan tetapi juga dengan konteks. Jika di dalam suatu dialog lisan, masing-masing pihak (pembicara dan pendengar) mengetahui konteks pembicaraan dan bila terjadi kesalah-pahaman di antara keduanya mereka dapat merujuk secara langsung kepada konteks apa yang sedang dibicarakan. Sebaliknya ketika membaca suatu teks kita sering kali mengalami kesulitan di dalam mengetahui apa konteks awal dari pembicaraan, walaupun kadang-kadang si pengarang telah mencoba menyelipkan konteks tersebut. Oleh karena itu adalah sangat mungkin terjadinya kesalahpahaman di dalam membaca suatu karya tulis kalau kita tidak mengetahui konteks pembicaraan (distanciated from the context). Lihat Suratno, "Pluralisme Agama dalam Hermeneutika Paul Richeur", WWW.Islamlib.com, didownlad pada tanggal 12 Agustus 2008.

${ }^{21}$ Abd. Muqsith Ghazali, "Merancang Kaidah Usul Fikih Baru," makalah diseminarkan pada acara Workshop JIL III, Jakarta: Wahid Institute, 2008, hal. 12. 


\section{Arif Susandi}

kemudian muncul menjadi sangat berbeda dengan kebanyakan ulama salaf. $^{22}$

Suatu tindakan yang sangat berani manakala Jaringan Islam Liberal menawarkan suatu cara pandang yang berbeda ketika melihat hukum Islam. Seperti apa yang di lontarkan oleh Muqsith Ghazali ${ }^{23}$ tentang hirarki sumber hukum Islam. Maqäsid al-shari'ah merupakan sumber hukum pertama dalam Islam, baru kemudian diikuti secara beriringan al-Qur'an dan al-Sunnah. Maqäsid al-sharì'ab merupakan inti dari totalitas ajaran Islam. Ia menempati posisi lebih tinggi dari ketentuan-ketentuan spesifik al-Qur'an. Maqāșid al-shari'ab ini merupakan sumber inspirasi tatkala al-Qur'an hendak menanam ketentuan-ketentuan legal spesifik di lapangan. Maqäsid al-shari'ah adalah sumber dari segala sumber hukum dalam Islam, termasuk sumber dari al-Qur'an sendiri. Oleh karena itu, sekiranya ada suatu ketentuan baik di dalam al-Qur'an maupun al-Hadis yang bertentangan secara substansif dengan maqāsid al-shari'ab maka ketentuan tersebut mesti direformasi. Ketentuan tersebut harus total atau dibatalkan demi logika maqāsid al-sharīah.

Secara garis besar penafsiran Jaringan Islam Liberal lebih mengutamakan realitas dari pada bunyi teks, meskipun lebih menonjolkan pertimbangan pada aspek realitas tetapi masih tetap menggunakan teks sebagai pijakan. Jaringan Islam Liberal mengkombinasikan antara teks dan konteks, pembahasan mengenai

${ }_{2}^{2}$ Para ulama salaf telah menetapkan manbajj (metode) menafsirkan Al-Quran. Pertama, untuk menafsirkan sebuah ayat harus terlebih dulu dicari tafsirnya dengan ayat yang lain, misalnya tentang hari kiamat (al-qäri'ab), apakah kiamat itu (mäal-qäri'ab), dan ayat seterusnya. Kedua, bila tidak ada ayat yang menafsirkan ayat tersebut, maka harus dicari dalam Sunnah (hadis) Nabi SAW. Ketiga, bila tidak juga ditemukan Sunnah yang menerangkan ayat tersebut, maka langkah selanjutnya dicarikan perkataan dari sahabat. Keempat, bila tidak ada perkataan sahabat mengenai tafsir sebuah ayat, maka dilacak dari perkataan para tabi' in, seperti Hasan Basri, Qatadah, Mujahid, dan lain-lain. Kelima, setelah perkataan generasi tabi'in pun tidak ada, baru dicarikan pendapat para imam, seperti Syafi'i, Maliki, Hanbali, dan Hanafi. Keenam, bila semua sandaran di atas juga tidak ditemukan, maka baru ayat tersebut ditafsirkan secara lughani (bahasa). Menurut Adian, selain metode di atas dianggap sebagai metode tafsir bi alráyi (dengan akal semata) atau dengan kata lain, menggunakan metode apa yang disebut hermeneutika. Lihat Adian Husaini, "Kritik Hermeneutika".

${ }^{23}$ Ghazali, "Merancang Kaidah", hal. 11. 
hal ini akan dijelaskan lebih lanjut pada bagian selanjutnya. Satu hal yang perlu penulis tekankan di sini, bahwa ijtihad yang dilakukan oleh Jaringan Islam Liberal dengan meninggalkan bunyi teks al-Qur'an telah dicontohkan oleh Khalifah Umar ibn Khattab. ${ }^{24}$

\section{Dekonstruksi Usul Fikih Menuju Usul Fikih Alternatif}

Barawal dari ketidakpuasan kalangan Islam liberal terhadap model metodologi Islam klasik yang dianggap rapuh, mereka berupaya merumuskan sebuah model baru metode penggalian hukum Islam. Muqsith Ghazali menjelaskan mengenai kerapuhan tersebut. Pertama, metodologi lama terlalu memandang sebelah mata terhadap kemampuan akal publik di dalam menyulih dan menganulir ketentuan legal formalistik di dalam Islam yang tidak lagi relevan. Kedua, metodologi klasik kurang peduli terhadap kemampuan manusia di dalam merumuskan konsep kemaslahatan walaupun untuk umat manusia sendiri, manusia tak memiliki reputasi dan kedudukan apa pun dalam ruang usul fikih klasik, kecuali menjadi sasaran hukum yang tak berdaya (mukallaf). Ketiga, pemberhalaan teks dan pengabaian realitas merupakan ciri umum metodologi lama. ${ }^{25}$

Mengenai konsep qiyas (analogi) yang terutama diusung oleh Syafi'i di mana ia didefinisikan sebagai menganalogikan sesuatu yang belum jelas ketentuan hukumnya (furu') dengan yang sudah jelas hukumnya dalam al-Qur'an dan al-Sunnah (aş) karena ada kesamaan 'illat, mereka menilai qiyas seperti ini bermasalah setidaknya karena dua hal berikut: ${ }^{26}$

\footnotetext{
${ }^{24}$ Virginia M. Hooker, "Developing Islamic Argument for Change Through Liberal Islam", WWW.Assyaukanie.com, didownlad pada tanggal 12 November 2008.

${ }^{25}$ Ghazali, "Metode dan Kaidah Penafsiran al-Qur'an", dalam Pemikiran Islam Kontemporer di Indonesia, (Yogyakarta: Pustaka Pelajar, 2005), hal. 138.

${ }^{26}$ Ghazali, "Menilik Metode Qiyas Syafi'i”, WWW.Islamlib.com, didownload pada tanggal 12 November 2008. Jaringan Islam Liberal juga menuduh kitab-kitab usul fikih klasik seperti al-Risälah karya Imam Syafi'i, diduga keras mengidap sejumlah persoalan yang kronis. Pertama, usul fikih Syafi'i beraroma Arabsentris. Arabisme merupakan ideologi yang lekat dalam tembok usul fikih lama. Kedua, kaidah yang banyak dilansir oleh kitab usul fikih Syafi'iyah yakni "al-ibrah bi 'umüm al-lafz là bi kbusüs al-sabab" terkesan terlalu memberhalakan teks dan mengabaikan konteks. Usul fikih konvensional lebih menitikberatkan pada lafz (kata) dan bukan pada maqāsid (ideal moral).
} 


\section{Arif Susandi}

1. Bahwa tidak ada dua peristiwa yang persis sama, sehingga hukum keduanya bisa diparalelkan. Persamaan illat yang menjadi alasan pengoperasian qiyas sesungguhnya merupakan tindakan simplifikasi.

2. Menyangkut hal-hal yang bersifat sosial, qiyas Syafi'i tampak mengabaikan konteks yang melandasi kehadiran hukum assl.

Setelah memberikan kritik terhadap metode usul fikih klasik, Jaringan Islam Liberal menawarkan kaidah usul fikih alternatif. Dari kaidah ini diharapkan dapat menjadi jembatan bagi kebuntuan usul fikih klasik dalam memecahkan kasus-kasus kontemporer. Adapun kaidah usul fikih tersebut adalah sebagai berikut:

1. Al-Tbrah bi al-Maqāsid là bi al-Alfäaz

Kaidah ini berarti bahwa yang mesti menjadi perhatian seorang mujtahid di dalam meng-istinbăt-kan hukum dari al-Qur'an dan al-Sunnah bukan huruf dan aksaranya melainkan dari maqäsid yang dikandungnya. Yang diperhatikan adalah cita-cita etik moral dari sebuah ayat dan bukan legislasi spesifik atau formulasi literalnya. ${ }^{27}$ Kaidah ini dimaksudkan untuk menguak makna di balik makna literal teks. Tidak lagi berkutat pada bunyi teks tapi hendak membuat suatu hukum yang bisa jadi sangat berbeda dengan bunyi teks. Menurut penulis, meskipun Jaringan Islam Liberal meninggalkan bunyi teks akan tetapi mereka tidak dapat lepas dari teks, hanya saja mereka menggunakan teks al-Qur'an sebagai pijakkan awal dalam menentukan hukum. Dengan menguak prinsip atau semangat al-Qur'an dari bunyi teks tersebut kemudian dari prinsip yang didapatkan dicoba untuk dikontekstualisasikan dengan zaman kini dan di sini (bukan Arab).

2. Jawäz Naskb al-Nușūs bi al-Maslaḅah

Al-Ṭūi menyatakan bahwa tidak mungkin terjadi pertentangan

${ }^{27}$ Ghazali, "Usul fikih Alternatif", wnnvislamlib.com, didownload pada tanggal 14 Juni 2008. Lihat juga dalam tulisan Muqsith lain mengenai usul fikih. 
antara nas dan maslabah, karena apa yang diujarkan oleh nas adalah kemaslahatan itu sendiri. ${ }^{28}$ Sering disinyalir bahwa kemaslahatan yang diandaikan oleh manusia adalah kemaslahatan semu dan relatif, sementara kemaslahatan yang ditetapkan Tuhan melalui bunyi harfiah nas adalah kemaslahatan hakiki dan obyektif. $^{29}$

Menurut Muqsith Ghazali teks baru bermakna sekiranya menyertakan cita kemaslahatan bagi umat manusia. Kemaslahatan merupakan ajaran agama yang thawäbit (tidak berubah, pokok, dan universal), sementara wujud pelaksanaan cita kemaslahatan itu merupakan perkara agama yang mutaghayyir (berubah-berubah mengikuti perubahan alur sejarah dan peradaban). Konsekuensinya naskb tidak dapat dilakukan terhadap teks al-Qur'an yang mengandung prinsip-prinsip ajaran yang universal, ajaran mana telah melintasi ruang dan waktu, mengatasi pelbagai etnis dan keyakinan. Ayat-ayat ini sebagai ayat dengan kedudukan paling tinggi (al-äyah al-ałlä qìmatan) atau al-āyah al-usūliyyah atau usūl al-Qur'an. Misalnya seperti ayat "wa idzā hakamtum bayna al-nās an tabkumū bi al'adl", "I'dilū buwa aqrab li al-taqwā", dan sebagainya. Sementara ayat-ayat mu'amalah dalam al-Qur'an yang bersifat teknis operasional, menurut Muqsith disebut dengan al-äyah al-adnā qimatan atau al-äyah alfuru'izyat atau fiqh al-Qur'an, seperti ayat yang berbicara tentang

${ }^{28}$ Pandangan al-Thufi tentang pertentangan antara nas dan maslabab ini dapat dilihat dalam tulisan Suraji, "Urgensi Teori Ma'labah Najmuddin al-Thufi dalam Pembaruan Hukum Islam Kontemporer”, dalam Jurnal Penelitian Agama, Vol. 5, no. 2, Juli-Desember, 2004, hal. 210. Menurut Suraji, al-Thufi tidak pernah mencontohkan adanya pertentangan antara nas dan maslabah.

${ }^{29}$ Ibid. hal. 212. Menurut Ibn Qudamah sebagaimana yang dikutip oleh Hafidz Abdurrahman, maslahab dibagi menjadi tiga yaitu maslabah mu'tabarah, yakni ma labah yang diterima dan dan diakui oleh syara', yaitu hukum yang ditarik dari rasionalitas al-Qur'an (ma'qul al-nașs) dan ijma'. Kemudian maslahab mulghiyah (maslabah yang ditolak) yaitu $m a^{\circ}$ labah ilusif yang kebatilannya telah dinyatakan oleh syara', karena bertentangan dengan al-Qur'an dan hadis dan jika diubah maka akan berakibat pada diubahnya hukum syara'; dan maslahab mursalab (maslahab yang tidak diterima dan tidak ditolak). Artinya maslabah ini tidak dinyatakan maupun ditolak dalam al-Qur'an maupun Hadis. Lihat Abdurrahman, Usul fikih, hal. 113-114. 
bentuk-bentuk hukuman ('uqübat $\bar{t}$ ), sanksi bagi para pelaku pidana (ḅudūd), bilangan waris dan sebagainya, maka tetap terbuka kemungkinan untuk dinasakh dan difalsifikasi, sekiranya ayat tersebut tidak efektif lagi sebagai sarana untuk mewujudkan cita kemalahatan. ${ }^{30}$

\section{Tanqīh al-Nusūs bi al-'Aql al-Mujtama'.}

Kaidah ini menyatakan bahwa akal publik memiliki kewenangan untuk menyulih dan mengamandemen sejumlah ketentuan "dogmatik" agama yang menyangkut perkara-perkara publik, baik dalam al-Qur`an maupun dalam al-Sunnah. Sehingga ketika terjadi pertentangan antara akal publik dengan bunyi harfiah teks ajaran, maka akal publik memiliki otoritas untuk mengedit, menyempurnakan, dan memodifikasikannya. Modifikasi ini terasa sangat dibutuhkan ketika berhadapan dengan ayat-ayat partikular, seperti ayat budūd (seperti potong tangan, rajam, dan sebagainya), waris, dan sebagainya. Ayat-ayat tersebut dalam konteks sekarang, alih-alih bisa menyelesaikan masalah-masalah kemanusian, yang terjadi justeru merupakan bagian dari masalah yang harus dipecahkan melalui prosedur tanqī bi al-'aql, takhsịis bi al-'aql, dan tabyin bi al-'aql."

\section{E. Penekanan Terhadap Prinsip Mașlaḥah dalam Istinbāt Hukum}

Maṣlạ̣ah berkonotasi jalb al-manäfi' (mengusahakan kemanfaatan) dan daf' al-mafasid (mencegah kerusakkan). ${ }^{32}$ Dalam

${ }^{30}$ Muqsith juga menambahkan bahwa ayat yang mengandung konsep toleransi adalah ayat pokok (usisil) sedangkan ayat kekerasan dan perang merupakan ayat cabang (furü). Lihat Adian Husaini, "Kritik Hermeneutika."

${ }^{31}$ Ghazali, "Usul fikih". Jaringan Islam Liberal tidak menjelaskan secara rinci apa yang dimaksud 'aql al-mujtama'. Akan tetapi menurut penulis setelah melacak di berbagai sumber, ia terkait juga dengan konsep kemaslahatan publik. Dalam menentukan kemaslahatan suatu hukum perlu diidentifikasi menggunakan berbagai ilmu, baik ilmu agama maupun ilmu sosial lain bahkan ilmu eksak. Kemudian dilakukan perumusan-perumusan yang melibatkan orang banyak (publik).

${ }^{32}$ Abdurrahman, Usul fikih, hal.113. 
khazanah usul fikih, maqāsid al-sharî'ah itu adalah keadilan, kemaslahatan, kesetaraan, hikmah-kebijaksanaan, dan cinta kasih. Maqāsid inilah yang sejatinya menjadi sumber inspirasi tatkala alQur'an hendak melabuhkan ketentuan-ketentuan legal-spesifik di lapangan. Dengan perkataan lain, maqāsid al-shari'ah adalah sumber dari segala sumber hukum dalam Islam, termasuk sumber dari alQur'an sendiri. ${ }^{33}$

Dalam syari'at terdapat beberapa varian yang mesti dipahami secara utuh, antara lain hukum, tujuan hukum, dalil, dan ijtihad. Hal ini menunjukkan bahwa syari'at tidak hanya hukum belaka, karena ada varian lain yang sangat penting yaitu tujuan-tujuan utama diturunkannya syari'at (maqäsìid al-shari'ab). ${ }^{34}$ Adapun kemaslahatan umum secara rinci ditujukan untuk memelihara agama, diri (jiwa), akal, keturunan, dan harta. Perlindungan terhadap kelima hal ini harus menjadi landasan utama dalam menetapkan produk hukum. Dalam upaya melindungi eksistensi kelima hal tersebut para ulama membagi dalam tiga tingkatan yakni:

\section{Darüriyyāt}

Pada tingkatan darüriyyât (primer) kelima hal tersebut harus diupayakan sebagai agenda utama. Apabila sarana itu tidak ada akan mengancam hilangnya perlindungan terhadap kelima hal tersebut. Sesuatu yang mutlak harus ada untuk menopang kehidupan manusia baik dalam urusan agama maupun keduniaan. Seandainya sesuatu itu tidak ada, maka rusaklah tata kehidupan ini. ${ }^{35}$ Menurut Jaringan Islam Liberal, yang dimaksud kemaslahatan primer yaitu perlunya melindungi agama, jiwa, akal, keturunan, dan harta. Setiap orang harus menghormati keberagamaan orang lain, menghargai jiwa, menghargai kebebasan berpikir dan berpendapat, menjaga keturunan (hak reproduksi) serta menghargai kepemilikan harta setiap orang.

${ }^{33}$ Ghazali, "Kaidah Usul Fikih."

${ }^{34}$ Nurcholis Madjid. dkk, Fiqib Lintas Agama (Jakarta: Paramadina, 2004) hal. 10.

${ }^{35}$ Danusiri, “Epistemologi Syara”', dalam Epistemologi Syara', ed. Anang Haris Himawan (Yogyakarta: Pustaka Pelajar, 2000), hal. 47. 
Kemaslahatan yang bersifat primer tersebut merupakan inti semua agama dan ajaran. ${ }^{36}$

2. Häjiyyāt

Hajizyyat adalah kemaslahatan yang bersifat sekunder, yaitu kemaslahatan yang tidak menyebabkan ambruknya tatanan sosial dan hukum. Misalnya dalam hal ibadat ada dispensasi atau rukhssah atau keringanan apabila dalam pelaksanaannya terdapat kesulitan. Bagi mereka yang melakukan perjalanan jauh, sakit dan orang tua renta diberikan keringanan dalam menjalakan ibadah. Menurut Islam Liberal kemaslahatan bajjyy $\overline{a t}$ ini menunjukkan adanya keringanan yang bertujuan untuk mewujudkan kemaslahatan dan kenyamanan bagi pemeluk agama. Dengan demikian beragama dan beribadah tidak akan ada rasa keberatan dan keterpaksan. Mengamalkan agama secara tulus ikhlas merupakan inti dari ibadah sehingga unsur keterpaksaan merupakan lawan yang sangat bertolak belakang. ${ }^{37}$

3. Tabsiniyyāt

Kemaslahatan taḥsiniyyät adalah kemaslahatan yang bersifat komplementer, yaitu kemaslahatan yang memberikan perhatian pada masalah etika dan estetika. Misalnya ajaran tentang kebersihan, berhias, sadaqah, dan bantuan kemanusiaan. kemaslahatan ini menyempurnakan kemaslahatan primer dan sekunder. $^{38}$

${ }^{36}$ Madjid, Figih Lintas Agama, hal. 11. Menurut kalangan Fundamentalis pendapat dari Jaringan Islam Liberal di atas sangat jauh berseberangan dengan usul fikih. Menurut mereka Jaringan Islam Liberal telah menyelewengkan apa yang telah termaktub dalam risalah-risalah tedahulu, bahwa menurut Usul fikih penjagaan terhadap agama adalah dalam bentuk ketentuan hukum syara' dengan membunuh orang kafir yang menyesatkan dan hukuman atas pembuat bid'ab yang mengajak kepada bid'ah. Hal ini dilaksanakan untuk menjaga agama. Menjaga atau melindungi agama adalah menjaga Islam agar tidak rusak, maka perusak agama dihukum bunuh. Dalam contoh di atas orang kafir yang menyesatkan hukumannya adalah dibunuh. Akan tetapi perlunya melindungi agama (bifz al-dîn) menurut kalangan fundamental telah dipelintir oleh Jaringan Islam Liberal menjadi "setiap manusia mesti menghargai keberagamaan orang lain." Lihat Hartono Ahmad Jaiz, "Nafsu Besar Tenaga Kurang", dalam WWW.Swaramustim.com.

${ }^{37}$ Madjid, Fiqih Lintas..., hal. 11.

${ }^{38} \mathrm{Ibid}$, hal. 11. Dalam hal bajijyyāt dan tabsinizyaat pertentangan antara fundamentalis 
Maslahat bersumber dari konteks sosial. Jika dalil agama bertentangan dengan konteks sosial, maka konteks harus didahulukan di atas teks agama. "Mendahulukan" dalam pandangan al-Tufi, bukan berarti membatalkan dan menganulir sama sekali dalil agama. Sebaliknya, konteks sosial dianggap sebagai "pen-takhșiș" atau spesifikasi dan "bayān" atau menerangkan teks atau dalil agama yang ada. Dalam hukum fikih fakta sosial jelas bisa menjadi dasar penetapan hukum. Karena itulah ada kaidah terkenal, "taghayyur alabkām bi taghayyur al-azmān wa al-amkinah." ${ }^{39}$

\section{F. Kesimpulan}

Kendati selalu menekankan dekonstruksi terhadap usul fikih klasik dan menyerukan pembaruan di dalamnya, penalaran hukum Jaringan Islam Liberal pd dasarnya masih tetap berpijak pada kaidah usul fikih lama. Indikasinya adalah bahwa penalaran hukum mereka masih berpijak pada al-Qur'an dan Hadis. Di samping itu mereka juga sering mengadopsi metode klasik lainnya misalnya 'urf, istihsān, dan juga konsep mașlahah yang digagas oleh para ulama klasik, meskipun pada beberapa sisi terdapat perbedaan. Atau lebih tepatnya adalah penekanan berbeda.

Sumber hukum Islam menurut Jaringan Islam Liberal adalah al-Qur'an dan Hadis. Akan tetapi pemahaman terhadap keduanya, menurut mereka, perlu menggunakan berbagai macam pendekatan, misalnya dengan hermeneutika. Jaringan Islam Liberal menjembatani ayat yang kontradiktif dengan konsep ayat ușül dan ayat fusül. Konsep ini menurut penulis adalah hasil turunan dari gagasan besar tentang maqāsid al-shari'ah. Ayat usül adalah ayat yang mengisyaratkan secara jelas akan gagasan maqāsid al-shari'ah, seperti ayat tentang pentingnya menegakkan keadilan, toleransi, dan saling menghargai keberagamaan. Sedangkan ayat fusū adalah ayat yang mengisyaratkan

dan liberalis kurang begitu mengemuka, perdebatan serius dan alot terjadi pada maslahat

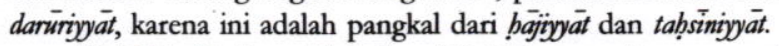

${ }^{39}$ Ulil Abshar Abdalla, "Kritik atas Argumen Aktivis Hizbut Tahrir," WWW.Islamlib.com, didownload pada tanggal 10 November 2008. 


\section{Arif Susandi}

adanya maqāsid al-shari'ab akan tetapi telah menjelma dalam konsep yang lokal (Arab). Misalnya ayat tentang perang terhadap orang kafir, pembagian waris, dan poligami.

Metode-metode yang digunakan oleh Jaringan Islam Liberal pada umumnya mengarah kepada makna di balik bunyi harfiah teks. Meninggalkan bunyi teks bukan merupakan kesalahan, asalkan masih dalam semangat al-Qur'an. Metode istibsän, 'urf, istisläh, dan yang semacamnya telah dimaknai secara lebih longgar oleh Jaringan Islam Liberal. Menurut penulis yang menjadi prioritas pertama adalah realitas, kedua adalah realitas, dan ketiga adalah realitas. Artinya kedudukan teks menjadi "kurang penting", ia hanya digunakan sebgai pelengkap dalam menyulih kebenaran. Jika terdapat dalil yang bertentangan dengan semangat toleransi misalnya, dalil itu harus ditafsir ulang atau bahkan ditolak. Jika ada dalil yang mendukung dengan gagasan itu maka akan diambil mentah-mentah tanpa interpretasi, meskipun dalil tersebut merupakan wilayah fușul (partikular). 


\section{DAFTAR PUSTAKA}

Abdalla, Ulil Abshar. Menyegarkan Kembali Pemikiran Islam. Jakarta: Nalar, 2007.

"Soal Kedudukan Hadis." islamliberal@yahoogroup.com . "Kritik atas Argumen Aktivis Hizbut Tahrir." WWW.Islamlib.com.

Abu Zaid, Nasr Hamid. Tekstualitas al-Qur'an, terj. Khoiron Nahdliyyin. Yogyakarta: LKIS, 2005.

Assyaukanie, Luthfi. "Merenungkan Sejarah al-Quran" dalam Ijtihad Islam Liberal.

Danusiri. "Epistemologi Syara" dalam Epistemologi Syara', ed. Anang Haris Himawan. Yogyakarta: Pustaka Pelajar, 2000.

Effendi, Satria. Usul fikih. Jakarta: Prenada Media, 2005.

Ghazali, Abd. Muqsith. "Metode dan Kaidah Penafsiran al-Qur'an", dalam Pemikiran Islam Kontemporer di Indonesia, ed. Abd. Muqsith Ghazali. Yogyakarta: Pustaka Pelajar, 2005. . "Menilik Metode Qiyas Syafi'i." WWW.Islamlib.com, . "Usul fikih Alternatif." WWW.Islamlib.com, . "Merancang Kaidah Usul fikih Baru," (makalah diseminarkan pada acara Workshop JIL III, Wahid Institute, Jakarta, 2008).

Hidayat, Komaruddin. Memahami Babasa al-Qur'an, Sebuab Kajian Hermeneutik. Jakarta: Paramadina, 1996.

Hoker, Virginia M. "Developing Islamic Argument for Change Through Liberal Islam." WWW Assyaukanie.com.

Husaini, Adian. "Kritik Hermeneutik al-Qur'an." $W W W$.islamlib.com. Ichwan, Mochamad Nur. Merintis Kesarjanaan Kritis al-Qur'an. Jakarta: Teraju, 2003.

" “Al-Qur'an sebagai teks, teori teks dalam hermeneutik al-Qur'an Nasr Hamid Abu Zaid', dalam Studi al-Qur'an Kontemporer, ed. Abdul Mustaqim dan Syahiron Syamsudin. Yogyakarta: Tiara Wacana, 2002. 
Jaiz, Hartono Ahmad. "Nafsu Besar Tenaga Kurang", WWW.Swaramuslim.com.

Kamali, Muhammad Hashim. Prinsip dan Teori-teori Hukum Islam. Yogyakarta: Pustaka Pelajar, 1996.

Kusmana. "Tafsir al-Qur'an Inklusif." WWW.islamlib.com.

Madjid, Nurcholis, dkk. Fiqih Lintas Agama. Jakarta: Paramadina, 2004.

Misrawi, Zuhairi. Al-Qur'an Kitab Toleransi. Jakarta: Fitrah, 2007.

Rahman, Yusuf. "Pluralitas Penafsiran al-Quran", dalam Ijtihad Islam Liberal.

Al-Sijistanī, Abū Dāwud Sulaiman al-Ash'ath. Sunan Abi Danud, 4 jilid. Beirut: Dar al-Hadis, 1999.

Suraji. "Urgensi Teori Ma labab Najmuddin al-Thufi dalam Pembaruan Hukum Islam Kontemporer", dalam Jurnal Penelitian Agama, Vol. 5, No. 2, Juli-Desember, 2004.

Suratno. "Pluralisme Agama dalam Hermeneutika Paul Richeur." WWW.Islamlib.com.

Syarifuddin, Amir. Usul fikib. Jakarta: Kencana, 2008. 